\title{
Development of Safety and Productivity Correlation Model for Tea Industries of Barak Valley, Assam
}

\author{
Dr S.K.Dey ${ }^{1}$ and Dr R.Gupta ${ }^{2}$ \\ ${ }^{1}$ Inspector of Factories, Government of Assam, India \\ ${ }^{2}$ Director, National Institute of Technology, Srinagar, J \& K, India
}

\begin{abstract}
The tea industries of Assam, India, are more than 150 years old. Though tea is an important class of industry in terms of employment and foreign exchange earning, the industry faces challenges from work place safety and declining productivity. A poor safety standard primarily originates from the belief that safety and productivity are mutually exclusive objectives, one eating away the other. But in practice they are correlated. The knowledge of exact nature of dependence of productivity with safety and health in a tea industry is therefore highly significant in the context of efficient tea production. In this paper, a quantitative relation between safety and productivity has been developed for tea industries of Barak valley, Assam. For this, safety and health in a tea industry have been modeled as function of four inputs such as occupational safety (OS), occupational health $(\mathrm{OH})$, behavioral safety (BS) and competency (C). Models for the assessment of the levels of these four inputs in a scale of 0 to 10 have been proposed. Data collected from 40 nos. of CTC tea manufacturing units situated in different locations of Barak valley, Assam, India. These data were regressed using regression software Eviews 3.1 to develop the correlation model between safety and productivity. The developed correlation, which is otherwise not available in the existing literature, would definitely contribute to change the management's erroneous mindset of treating safety as a liability to the business.
\end{abstract}

Keywords: Productivity, Safety, occupational health, behavioral safety.

\section{INTRODUCTION}

Safety and health of workers in tea production is traditionally regarded as an extraneous obligation that offsets productivity improvements. The tea industries located in Barak valley, Assam, India, faces challenges in ensuring occupational safety and health because of two fold reasons. First, its management's erroneous mindset of accepting safety as a liability to the business and secondly, the lack of safety awareness amongst the workers. The challenges have aggravated with the globalization of trade, competitions from the newly emerging tea producing countries and demand for more productivity especially in the backdrop of the rural and orthodox background of tea workers. Around $80 \%$ of the accidents occurring in the tea estates of Assam are due to human error or in other words, one can term them as due to unsafe acts. Further, the productivity performance of the tea industries of Barak valley, Assam is on decline owing to the fact that cost of production of tea has risen exponentially on one hand and the prices of tea has remained mostly stagnant or declining. In a nutshell, the productivity and safety performances of the tea industries of Assam have been discouraging in the recent past, a phase it must get rid of for its survival and efficient operation. So, there is an urgent need to see that whether there exists a correlation between the safety and productivity so that they can be easily integrated economically and effectively in a holistic manner resulting in reduction of cost, enhanced productivity through safety and elimination of separate policy framing for safety and productivity. With the correlation model in hand, the managements of tea industry would be able to achieve a proper blending of safety and productivity.

\section{BRIEF LITERATURE REVIEW}

Islam et al. [1] studied the present condition and support needed for the development of the tea industry of Bangladesh. Jayatilake [2] applied the stochastic frontier approach to estimate the technical efficiency of the tea manufacturing firms in Srilanka. The study identified that the production capacity of tea factories varied between three tea producing regions of Sri Lanka. Felthoven et al. [3] used a parametric primal productivity model, based on a second order approximation of a transformation function, to econometrically estimate productivity patterns and their determinants for the Bering sea and Aleutian islands (BSAI) Pollock fishery. Hafezi et al. [4] investigated the optimum fermentation times of black tea manufactured by two systems of manufacture, namely orthodox and CTC by measuring quality parameters of black tea. Gesimba et al. [5] provided a summary of significant aspects of Kenyan tea industry and positive developments. Saha et al. [6] examined the economic profitability of tea cultivation in Bangladesh. Baten et al. [7] measured the status of 
technical efficiency of tea producing industry for panel data in Bangladesh, using stochastic frontier productive function, incorporating technical inefficiency effect model. Kamau [8] assessed the trends in yields by analyzing long term tea production data from 1969 to 2006, for the two sectors of the Kenyan tea industry. Tomling and Mashingaidze [9] reviewed the literature on the influence of withering on maceration, fermentation, drying and on black tea quality. Emaldi et al. [10] used central composite design technique, a response surface methodology to study the effect of the withering time and the fermentation conditions of the tea leaves on the black tea quality parameters. Marlowe and Mansfield [11] assessed the past and current environment, health and safety performance of the cement industry and identified the key actions that would help drive the cement industry to contribute to a more sustainable society. Taiwo [12] analyzed the impact of work environment on workers productivity in oil and gas industry in Lagos metropolis. Bad working conditions contribute to low productivity of employees. Whittaker et al. [13] studied safety and health status in collision repair industries of Washington State, wherein the workers might be exposed to isocyanates and other harmful chemicals. Goodier et al. [14] conducted a study to assess and / or evaluate the existing standards and safety and health conditions in a broad representative scope of abrasive blast cleaning operations within various U.S. industries. Donoghue [15] used a walk-through survey of an underground metalliferous mine and concentrator to demonstrate how qualitative matrix can be applied to determine priorities for control of occupational health hazards. Wan [16] carried out occupational health and safety risk assessment of child workers in carpet weaving industries of Pakistan. He identified that the hazards of carpet weaving process are skeletal deformation, eye sight disorder and mechanical and toxic hazards. Mamba [17] conducted a study in the city of Mbabane on occupational health and safety assessment in the informal car maintenance, welding and sprays painting industry.

From above, it is observed that no systematic study to explore the correlation between productivity and safety in tea industries has been reported so far.

\section{TEA PROCESSING}

Tea processing is a simple process, but it is emphasized that numerous factors affect the final product. The chain of operations involved in tea processing can be distinguished as (Figure 1)

i) Withering.

ii) Leaf distortion.

iii) Fermentation.

iv) Drying.

v) Sorting and grading.

Figure 1. Different stages of manufacturing processes for black tea.

\section{SAFETY AND HEALTH SCENARIO IN THE TEA INDUSTRIES OF ASSAM}

Workplace safety and health has a great influence on the productivity of the entire manufacturing activity. For a labour intensive industry like tea, where the labourers are illiterate, unskilled and malnourished and also which is striving for enhancement of productivity, safety and health of workers need to be paid special attention. Safety and health of workers is regarded by the stake holders of the tea industry as an out of the core activities of tea production even today. Accidents occur in the tea industries in the form of minor, serious and fatal accidents along with dangerous occurrences on a regular frequency. But, a safe work environment is also productive work site. Therefore, safety and health in the tea industries need to be improved on urgent basis. Every year a good number of accidents are taking place in the tea industries. Further, every year there are fatal accidents taking place at an alarming rate claiming precious human lives.

The prime causes of accidents occurring in tea industries are listed as below:

- More manual operation rather mechanisation in production process.

- Lower economic, social and educational status of the tea workers.

- The attitude of the management towards accidents is that it is inevitable, i.e. Act of god.

- Management, trade union and workers are not adequately conscious of the high cost of accidents.

- Lack of visible and felt leadership across all level.

- Absence of well trained safety cell.

- Belief amongst the workers that safety is the function of only the manager.

- Continuation of dangerous or non-conforming habits.

- Instead of preventive action the prevalent mindset of corrective action.

- An improvement of safety standards is viewed as the out flow of fund.

- Treating safety expenditures as a factor which reduces productivity.

- Unsafe act.

- Unsafe condition. 
- Poor house keeping.

Also, with a productivity measurement model for tea industry in hand, any step for development of mutual dependence of productivity and safety and health status in tea industries, quantification of safety and health status is of paramount importance.

\subsection{Occupational safety and health hazards in tea processing}

Following occupational health and safety hazards are encountered during tea processing activities

- Physical hazards

- Thermal radiation

- Respiratory hazards

- Electrical hazards

- $\quad$ Fire and explosions

\subsection{Elements of accident cost}

Industrial accidents are defined as any unplanned event that result in the any or combination of the following consequences

i) Physical injury.

ii) Loss of production time.

iii) Loss of property.

Accidents always attend with a cost. They take away a part of total achievement and have an adverse effect on productivity.

\subsection{Need for safety and health in tea industries}

Statistics of accidents reveals that every year a good number of accidents are taking place in the tea industries of Assam including fatality causing physical injury, disability, property loss and loss of production time. So, it is required to prevent accident by introducing safety and health in tea factories, because of humanitarian ground, economic consideration and legal obligation.

\section{MODEL FOR THE ASSESSMENT OF SAFETY AND HEALTH IN TEA} INDUSTRIES

All the factors affecting safety and health in a tea industry are identified and enlisted under four broad categories such as occupational safety (OS), occupational health (OH), behavioral safety (BS) and competency (C). Tables 1 to 4 describe models for the assessment of the levels of these four inputs in a scale of 0 to 10 . In these proposed models, the numerical values of weights, assigned to each of the safety elements, are based on the relative significance of the elements to cause harmful events due to their poor standard or non-existence and depend on the subjective judgement and experience of the evaluator. Summation of all the weights in a particular category of the inputs is one. Rating is assigned to each element depending again on the expert human knowledge and experience of the evaluator regarding the quality of the preventive measure for that element after examining it from all relevant aspects.

Table 1. Assessment of occupational safety (OS) score.

\begin{tabular}{|l|l|l|l|l|l|}
\hline Sl.no. & Elements of occupational safety & weight & $\begin{array}{l}\text { Rating } \\
(\%)\end{array}$ & $\begin{array}{l}\text { Weighted } \\
\text { rate }\end{array}$ & $\begin{array}{l}\text { Score=(weighted } \\
\text { rate }) \div 10\end{array}$ \\
\hline 1 & Guarding of machines & & & & \\
\hline 2 & Electrical safety & & & & \\
\hline 3 & Fire safety & & & & \\
\hline 4 & Walk ways, stair case & & & & \\
\hline 5 & $\begin{array}{l}\text { Lifting tackles, chain pulleys \& } \\
\text { pressure vessels }\end{array}$ & & & & \\
\hline 6 & Procedures & & & & \\
\hline 7 & $\begin{array}{l}\text { Personnel protective equipments } \\
\text { (PPE) }\end{array}$ & & & & \\
\hline 8 & Boiler safety & & & & \\
\hline 9 & Building safety & & & & \\
\hline 10 & Machine safety & & & & \\
\hline
\end{tabular}

Table 2. Assessment of occupational health $(\mathrm{OH})$ score. 


\begin{tabular}{|l|l|l|l|l|l|}
\hline Sl.no. & $\begin{array}{l}\text { Elements of } \\
\text { occupational health }\end{array}$ & weight & Rating (\%) & $\begin{array}{l}\text { Weighted } \\
\text { rate }\end{array}$ & $\begin{array}{l}\text { Score }=(\text { weighted } \\
\text { rate }) \div 10\end{array}$ \\
\hline 1 & Ergonomics & & & & \\
\hline 2 & Noise & & & & \\
\hline 3 & $\begin{array}{l}\text { Ventilation and } \\
\text { temperature }\end{array}$ & & & & \\
\hline 4 & $\begin{array}{l}\text { Fibre and dust removal } \\
\text { system }\end{array}$ & & & & \\
\hline 5 & House keeping & & & & \\
\hline 6 & Drinking water & & & & \\
\hline 7 & Latrines and urinals & & & & \\
\hline
\end{tabular}

Table 3. Assessment of behavioral safety (BS) score.

\begin{tabular}{|l|l|l|l|l|l|}
\hline Sl.no. & Elements of behavioral safety & weight & Rating (\%) & $\begin{array}{l}\text { Weighted } \\
\text { rate }\end{array}$ & $\begin{array}{l}\text { Score=(weighted } \\
\text { rate) } \div 10\end{array}$ \\
\hline 1 & Worker attitude & & & & \\
\hline 2 & Worker moral & & & & \\
\hline 3 & $\begin{array}{l}\text { Management commitment \& } \\
\text { co-operation }\end{array}$ & & & & \\
\hline 4 & Compliance to statutory laws & & & & \\
\hline 5 & Safety policy and planning & & & & \\
\hline
\end{tabular}

Table 4. Assessment of competency (C) score.

\begin{tabular}{|l|l|l|l|l|l|}
\hline Sl.no. & Elements of competency & weight & $\begin{array}{l}\text { Rating } \\
(\%)\end{array}$ & $\begin{array}{l}\text { Weighted } \\
\text { rate }\end{array}$ & $\begin{array}{l}\text { Score }=(\text { weighted } \\
\text { rate }) \div 10\end{array}$ \\
\hline 1 & Skill & & & & \\
\hline 2 & Training & & & & \\
\hline 3 & $\begin{array}{l}\text { Safety information \& } \\
\text { deployment }\end{array}$ & & & & \\
\hline
\end{tabular}

\section{DEVELOPMENT OF SAFETY AND PRODUCTIVITY CORRELATION MODEL} FOR TEA INDUSTRIES

There is quite a variety of factors which can affect productivity, both positively and negatively. These include: 1) capital investments in production, 2) capital investments in technology, 3) capital investments in equipment, 4) capital investments in facilities, 5) economies of scale, 6) workforce knowledge and skill resulting from training and experience, 7) technological changes, 8) work methods, 9) procedures, 10) systems, 11) quality of products, 12) quality of processes, 13) quality of management, 14) legislative and regulatory environment, 15) general levels of education, 16) social environment and 17) geographic factors.

The first four factors of productivity are reflected in cost per $\mathrm{kg}$ of made tea. All the tea factories of Barak valley has been assumed to reaped the benefit of economies of scale. Factors 14, 15, 16 and 17 are uniform for all the tea factories of the region and hence are not expected to influence the correlation between safety and productivity. An element of quality is included in the output price (selling price). The remaining factors are also elements of safety and health. Therefore, the variables that influence the correlation between productivity and safety and health in the CTC tea manufacturing units of Barak valley are output price per $\mathrm{kg}$ of tea made, Cost per $\mathrm{kg}$ of made tea, and four inputs of safety and health such as occupational safety (OS), occupational health $(\mathrm{OH})$, behavioral safety (BS) and competency (C). For development of the correlation, data were collected on input cost and output price per $\mathrm{kg}$ of tea made from 40 nos. of CTC tea manufacturing units of Barak valley. The collected data along with the computed total factor productivity (TFP) are given in Table 5.

Table 5. Input cost, output price and total factor productivity for tea industries of Barak valley

\begin{tabular}{|l|l|l|l|l|}
\hline $\begin{array}{l}\text { Sl. } \\
\text { No. }\end{array}$ & Name of the tea estate & $\begin{array}{l}\text { Average sell } \\
\text { price per kg } \\
\text { of made tea } \\
\text { for 2010 }(\mathrm{Rs})\end{array}$ & $\begin{array}{l}\text { Average input } \\
\text { cost per kg of } \\
\text { made tea for 2010 } \\
(\text { Rs) }\end{array}$ & $\begin{array}{l}\text { Total factor } \\
\text { productivity }= \\
\text { \{Column }(3) \div \\
\text { Column }\end{array}$ \\
\hline 1 & Rosekandi tea estate, Cachar & 130 & 64 & 2.03 \\
\hline
\end{tabular}




\begin{tabular}{|c|c|c|c|c|}
\hline 2 & Binakandi tea estate, Cachar & 130 & 68 & 1.91 \\
\hline 3 & Borojalinga tea estate, Cachar & 80 & 55 & 1.45 \\
\hline 4 & Silcoorie tea estate, Cachar & 102 & 62 & 1.64 \\
\hline 5 & West jalinga tea estate, Cachar & 82 & 60 & 1.37 \\
\hline 6 & Borokoi tea estate, Cachar. & 60 & 55 & 1.09 \\
\hline 7 & Pollarbund tea estate, Cachar. & 90 & 62 & 1.45 \\
\hline 8 & $\begin{array}{l}\text { Avishek tea industry, } \\
\text { Hailakandi. }\end{array}$ & 90 & 60 & 1.5 \\
\hline 9 & Bikrampur tea estate, Cachar. & 93 & 68 & 1.37 \\
\hline 10 & $\begin{array}{l}\text { Coombhergram tea estate, } \\
\text { Cachar }\end{array}$ & 92 & 75 & 1.23 \\
\hline 11 & Monierkhal tea estate, Cachar. & 100 & 63 & 1.59 \\
\hline 12 & Cossipore tea estate, Cachar & 95 & 62 & 1.53 \\
\hline 13 & Koomber tea estate, Cachar. & 93 & 76 & 1.22 \\
\hline 14 & Labac tea estate, Cachar. & 86 & 70 & 1.22 \\
\hline 15 & Jellalpur tea estate, Cachar. & 85 & 72 & 1.18 \\
\hline 16 & Chandighat tea estate, Cachar. & 98 & 72 & 1.36 \\
\hline 17 & Urrnabund T.E. & 98 & 70 & 1.4 \\
\hline 18 & Rampore T.E. & 92 & 61 & 1.51 \\
\hline 19 & Dewan T.E. & 80 & 70 & 1.14 \\
\hline 20 & Burtoll T.E. & 85 & 70 & 1.21 \\
\hline 21 & Pathini T.E. & 77 & 70 & 1.10 \\
\hline 22 & Kalline T.E. & 85 & 72 & 1.18 \\
\hline 23 & Kallincherra T.E. & 55 & 70 & 1.27 \\
\hline 24 & Kanchanpur T.E. & 80 & 64 & 1.25 \\
\hline 25 & Lalacherra T.E. & 62 & 65 & 0.95 \\
\hline 26 & Borokoi T.E. & 62 & 58 & 1.07 \\
\hline 27 & Abhishek T.E. & 98 & 62 & 1.58 \\
\hline 28 & Roopacherra T.E. & 102 & 63 & 1.62 \\
\hline 29 & Martycherra T.E. & 100 & 65 & 1.53 \\
\hline 30 & Dullavcherra T.E. & 100 & 70 & 1.43 \\
\hline 31 & Poloi T.E. & 91 & 66 & 1.37 \\
\hline 32 & Narsinghpur T.E. & 95 & 64 & 1.48 \\
\hline 33 & Derby T.E. & 80 & 68 & 1.17 \\
\hline 34 & Sephinjuribheel T.E. & 105 & 68 & 1.54 \\
\hline 35 & Doyapur T.E. & 70 & 60 & 1.16 \\
\hline 36 & Hilara T.E. & 60 & 64 & 0.94 \\
\hline 37 & Degubber T.E. & 60 & 55 & 1.09 \\
\hline 38 & Lalamookh T.E & 100 & 74 & 1.35 \\
\hline 39 & Vernerpur T.E. & 125 & 65 & 1.92 \\
\hline 40 & Dholai T.E. & 94 & 65 & 1.44 \\
\hline
\end{tabular}

Source: Respective tea estates

The four inputs of safety and health for each of the 40 CTC tea industries of Barak valley under consideration were evaluated on the basis of models proposed in the section 5.0 (Tables 1 to 4) and are presented in Table 6 along with cost and TFP of respective tea industries.

Table 6. Assessed safety elements and TFP of the CTC tea Industries of Barak valley.

\begin{tabular}{|c|c|c|c|c|c|c|c|}
\hline 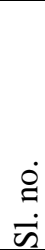 & 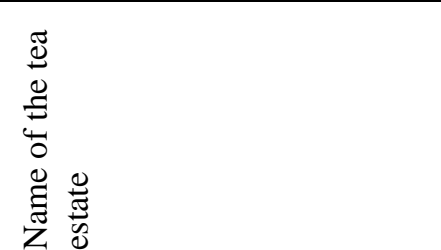 & 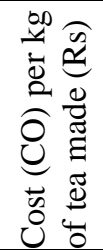 & 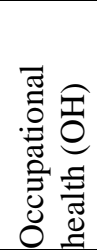 & 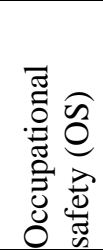 & 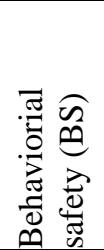 & 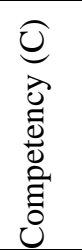 & 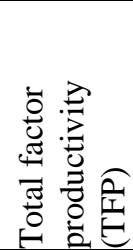 \\
\hline 1 & Rosekandi tea estate, Cachar & 64 & 7.25 & 6.3 & 7.1 & 6.75 & 2.03 \\
\hline 2 & Binakandi tea estate, Cachar & 68 & 6.5 & 6 & 5 & 5 & 1.91 \\
\hline 3 & Borojalinga tea estate, Cachar & 55 & 4 & 4 & 4.5 & 4 & 1.45 \\
\hline
\end{tabular}




\begin{tabular}{|l|l|l|l|l|l|l|l|}
\hline 4 & Silcoorie tea estate, Cachar & 62 & 5 & 5.2 & 5 & 4.9 & 1.64 \\
\hline 5 & West jalinga tea estate, Cachar & 60 & 4 & 4.5 & 4.2 & 4 & 1.37 \\
\hline 6 & Bhubandar tea estate, Cachar. & 55 & 4 & 4 & 3 & 3 & 1.09 \\
\hline 7 & Pollarbund tea estate, Cachar & 62 & 4 & 4 & 4 & 3 & 1.45 \\
\hline 8 & Ramavtarjee tea Co, Hailakandi. & 60 & 4.9 & 4.8 & 4 & 4 & 1.5 \\
\hline 9 & Bikrampur tea estate, Cachar. & 68 & 6 & 6 & 4 & 3 & 1.37 \\
\hline 10 & Coombhergram tea estate, Cachar & 75 & 4 & 4 & 4 & 3.5 & 1.23 \\
\hline 11 & Monierkhal tea estate, Cachar. & 63 & 4 & 5 & 6 & 4 & 1.59 \\
\hline 12 & Cossipore tea estate, Cachar & 62 & 4 & 5 & 5 & 3 & 1.53 \\
\hline 13 & Koomber tea estate, Cachar. & 76 & 5 & 4 & 3 & 4 & 1.22 \\
\hline 14 & Labac tea estate, Cachar. & 70 & 4 & 5 & 3 & 3 & 1.22 \\
\hline 15 & Jellalpur tea estate, Cachar. & 72 & 3.8 & 4 & 3 & 3 & 1.18 \\
\hline 16 & Chandighat tea estate, Cachar. & 72 & 4.8 & 5 & 4.5 & 4 & 1.36 \\
\hline 17 & Urrnabund T.E. & 70 & 3 & 3 & 3 & 3 & 1.4 \\
\hline 18 & Rampore T.E. & 61 & 4 & 4 & 4.5 & 4 & 1.51 \\
\hline 19 & Dewan T.E. & 70 & 3.6 & 4 & 3 & 3 & 1.14 \\
\hline 20 & Burtoll T.E. & 70 & 3.7 & 4.2 & 3 & 3 & 1.21 \\
\hline 21 & Pathini T.E. & 70 & 3 & 3 & 3 & 3 & 1.10 \\
\hline 22 & Kalline T.E. & 72 & 3.5 & 3 & 3 & 3 & 1.18 \\
\hline 23 & Kallincherra T.E. & 70 & 3 & 3 & 3 & 3 & 1.27 \\
\hline 24 & Kanchanpur T.E. & 64 & 3 & 3.5 & 5 & 4 & 1.25 \\
\hline 25 & Lalacherra T.E. & 65 & 2 & 1.5 & 3 & 3 & 0.95 \\
\hline 26 & Borokoi T.E. & 58 & 3 & 4 & 3 & 3 & 1.07 \\
\hline 27 & Abhishek T.E. & 62 & 5 & 4 & 5 & 3 & 1.58 \\
\hline 28 & Roopacherra T.E. & 63 & 4 & 5 & 5 & 3 & 1.62 \\
\hline 29 & Martycherra T.E. & 65 & 5 & 5 & 5 & 3 & 1.53 \\
\hline 30 & Dullavcherra T.E. & 70 & 4 & 4 & 4.5 & 3 & 1.43 \\
\hline 31 & Poloi T.E. & 66 & 4 & 4 & 3.8 & 3 & 1.37 \\
\hline 32 & Narsinghpur T.E. & 64 & 4.2 & 4 & 5 & 4 & 1.48 \\
\hline 33 & Derby T.E. & 68 & 3 & 3 & 2 & 3 & 1.17 \\
\hline 34 & Sephinjuribheel T.E. & 68 & 5 & 5 & 5 & 4 & 1.54 \\
\hline 35 & Doyapur T.E. & 60 & 2 & 2 & 3 & 3 & 1.16 \\
\hline 36 & Hilara T.E. & 64 & 2 & 2 & 2 & 2 & 0.94 \\
\hline 37 & Degubber T.E. & 74 & 2 & 2 & 3 & 3 & 1.09 \\
\hline 38 & Lalamookh T.E & 65 & 4.5 & 4 & 5 & 3 & 1.35 \\
\hline 39 & Vernerpur T.E. & 65 & 4.5 & 4 & 6 & 3 & 1.92 \\
\hline 40 & Dholai T.E. & & & & & & 1.44 \\
\hline & & 74 & 5 & 3 & \\
\hline
\end{tabular}

TFP was regressed with the variables of $\mathrm{CO}$ (Cost), $\mathrm{OH}, \mathrm{OS}, \mathrm{BS}$ and $\mathrm{C}$ using regression software Eviews 3.1 to obtain the following regression equation $\mathrm{TFP}=0.6893753508-0.002766769735 * \mathrm{CO}+0.1313516708 * \mathrm{BS}+0.08458578836 * \mathrm{OH}-$ $0.005081060392 * \mathrm{OS}+0.003596757416 * \mathrm{C}$

Figure 2. confirms a good fit between the actual and fitted values of TFP. The regression equation depicts a correlation between the safety and health and productivity of the tea industries of Barak valley, Assam, through cost. Since this equation has been developed on the background of CTC method of tea processing, the regressed equation is valid for all the tea industries of Barak valley. 


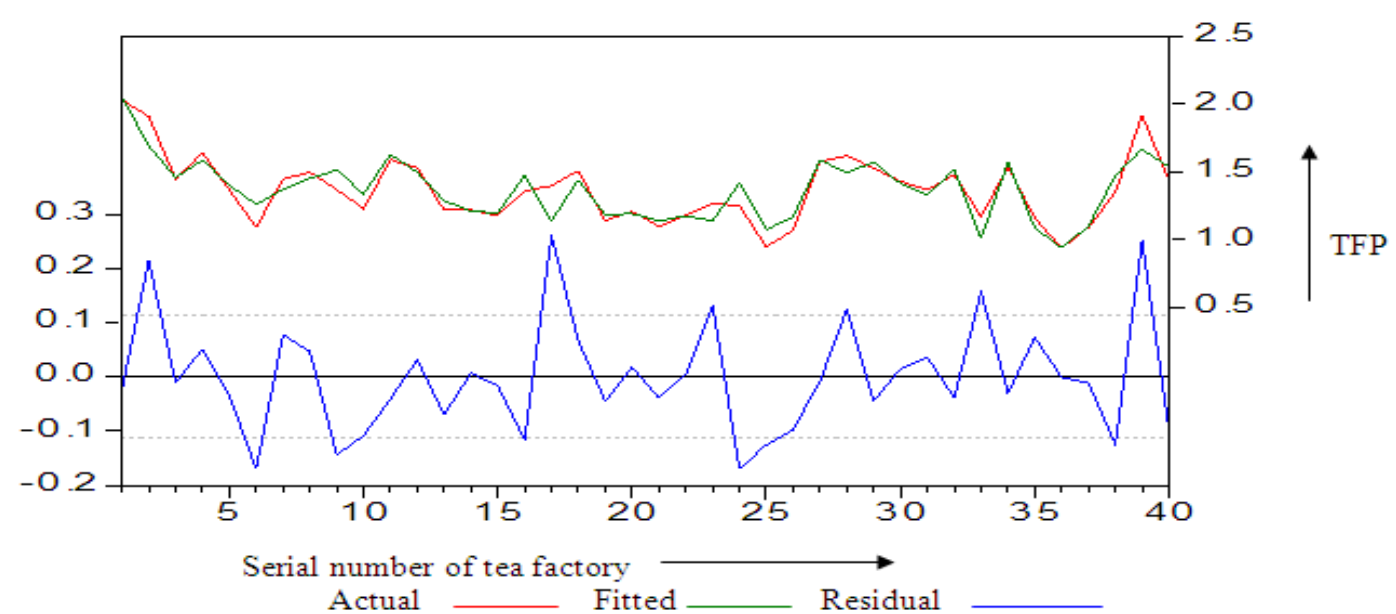

Figure 2. Graph showing the actual and fitted values of TFP

\section{CONCLUSIONS}

Safety and health of workers are extremely important aspect of tea production which is not given its due importance in the tea processing units of Barak valley. Using data on cost of production and average sale price of 40 nos. of CTC tea manufacturing units of Barak valley, correlation between productivity and safety was developed. For this, scores on the four inputs of safety such as occupational safety (OS), occupational health $(\mathrm{OH})$, behavioral safety (BS) and competency (C) were evaluated for each of the 40 nos. of CTC tea units using the proposed models to evaluate them. The developed correlation is a functional relation between total factor productivity and four safety elements and cost of production. Hence, the developed correlation can be used to predict total factor productivity (TFP) from the knowledge of the values of input safety elements and planned cost of production.

\section{REFERENCES}

1). G.M.R. Islam, M. Iqbal, K.G. Kuddus and M.Y. Ali, "Present status and future needs of tea industry in Bangladesh”, Proc. Pakistan Acad. Sci. 42 (4): 305-314, 2005.

2). J.C. Rohan Jayatilake, "The estimation of technical efficiency of tea manufacturing firms in Srilanka: a stochastic frontier analysis", Annual research journal of SLSAJ, issue 6 (90-94). 2007.

3). R.G. Felthoven, C.J. Morrison and Torres, M., "Measuring productivity change and its components for fisheries: The case of Alaskan Pollock Fishery, 1994-2003", International association of agricultural economists conference, Gold coast, Australia, 2006.

4). M. Hafezi, B. Nasernezad and F. Vahabzadeh, "Optimization fermentation time for Iranian black tea production”, Iran. J. Chem. Chem. Eng., Vol. 25, No. 1, pp. 39-44, 2006.

5). R.M. Gesimba, M.C. Langat, G. Liu and J.N. Wolukau, "The Tea Industry in Kenya; The Challenges and Positive Developments", Journal of Applied Sciences, 5 (2): 334-336, 2005.

6). J.K. Saha, F. Alam and A. Bashar, "Economics made tea cultivation in Bangladesh", Two and a bud, 50: 42-49, 2003.

7). A. Baten, A.A. Kamil and A. Haque, "Productive efficiency of tea industry: A stochastic frontier approach", African journal of Biotechnology, vol. 9 (25), pp. 3808-3816, $21^{\text {st }}$ June, 2010.

8). D.M.Kamau, "Productivity and resource use in ageing tea plantations", $\mathrm{PhD}$ theisis, Wageningen university, ISBN: 978-90-8504-808-4, 40pp, 2008.

9). K.I. Tomling and A. Mashingaidze, "Influence of withering including leaf handling on the manufacturing and quality of black teas- a review", Food chemistry, vol. 60, No. 4, pp. 573-580, 1997.

10). L. Emaldi, B. Nasernezad, S.T. Shokrgozar, M. Mehranian and F. Vahabzadeh, "Optimization of withering time and fermentation condition during the manufacture of black tea using a response surface methodology", Chemistry and chemical

11). I. Marlowe And D. Mansfield, "Toward a sustainable cement industry", Sub study 10, Environment, health \& safety performance improvement, World business council for sustainable development, December, 2002.

12). A.S. Taiwo, "The influence of work environment on worker's productivity: A case of selected oil and gas industry in Lagos, Nigeria", African journal of business management, vol. 4(3), pp. 299-307, March, 2010. 
13). S.G. Whittaker, R. Anderson and C. Whittaker, "Health and safety in Washington state's collision repair industry: A needs assessment", Technical report 69-4-2005. Safety \& Health Assessment \& Research for Prevention, Washington State Department of Labor and Industries, Olympia, Washington. December, 2005.

14). J.L. Goodier, E. Boudreau, G. Coletta and R. Lucas, "Industrial health and safety criteria for abrasive blast cleaning operations", U.S. department of health, education and welfare, Public health service, Center for disease control, National institute for occupational safety and health, Cincinnati. Ohio, Tech. rep, HSM 99-72-83, September,1974.

15). A.M. Donoghue, "The design and hazard risk assessment matrices for ranking occupational health risks and their application in mining and minerals processing", Occup. Med, Vol. 51, No. 2, pp.118-123, 2001.

16). S.A. Awan, "Occupational health and safety assessment of child workers in carpet weaving industry", Center for the improvement of working conditions and environment, Lahore, December, 2001.

17). R.M. Mamba, "An assessment of occupational health and safety in the informal car maintenance, welding and spray painting industry in Mbabane", M. Ph research report, 2007 [online], Available http://hdl.handle.net/10539/2045 